\title{
Relationship between High School Principals' Humor Styles and Teacher Leadership
}

\author{
Ali Çağatay Kılınç ${ }^{1, *}$, Ergün Recepoğlu ${ }^{2} \&$ Serkan $\operatorname{Koşar}^{3}$ \\ ${ }^{1}$ Department of Educational Sciences, Faculty of Letters, Karabuk University, Karabuk, \\ Turkey \\ ${ }^{2}$ Department of Educational Sciences, Faculty of Education, Kastamonu University, \\ Kastamonu, Turkey \\ ${ }^{3}$ Department of Educational Sciences, Faculty of Education, Gazi University, Ankara, Turkey \\ *Corresponding author: Karabuk University Iron and Steel Campus, 78050, Karabuk, Turkey. \\ Tel: 90-370-433-8294. E-mail: cagataykilinc@karabuk.edu.tr
}

Received: July 31, 2014 Accepted: September 3, 2014 Published: September 23, 2014

doi:10.5296/ije.v6i3.6050 URL: http://dx.doi.org/10.5296/ije.v6i3.6050

\begin{abstract}
This study aimed at examining the relationship between high school teachers' perceptions of teacher leadership and school principals' humor styles. A total of 252 teachers employed in 12 high schools located in the city centre of Ankara, Turkey participated in the study. "The Humor Behavior Scale" developed by Cemaloğlu, Recepoğlu, Şahin, Daşçı and Köktürk (2013) and "The Teacher Leadership Scale" developed by Beycioğlu and Aslan (2010) were used to gather data. Results of the study indicated that productive-social humor style was positively and significantly correlated with such dimensions of teacher leadership as institutional improvement, professional improvement, and collaboration among colleagues. Results also revealed that the productive-social humor style was a significant predictor of institutional improvement and professional improvement. Results were discussed within the context of the improvement of the leadership behaviors of teachers.
\end{abstract}

Keywords: humor styles, teacher leadership, high school, Turkey 


\section{Introduction}

Laughing is an instinctive human behavior. These behaviors refer to a universal body language that shows the degree to what an individual is content with the environment or situation $\mathrm{s} /$ he is in. Humor refers to all conditions mediating the acts of laughing and amusing. Humor is widely regarded as a desirable and positive personality trait (Altınkurt \& Y1lmaz, 2011). From this perspective, humor is a positive concept that is important in every organization and directs the actions of employees. The use of humor in leadership provides many benefits (Clouse \& Spurgeon, 1995). Two characteristics which researchers associate with humor often are effective leadership and the capability of leaders to achieve change among followers (Avolio, Howell, \& Sosik, 1999; Barbour, 1998; Bass, 1990; Caudron, 1992; Conger, 1989; Dwyer, 1991; Duncan, 1982; Gruner, 1997; Hogan, Curphy, \& Hogan, 1994; Farrell, 1998; Kahn, 1989; Safferstone, 1999; Shamir, 1995; Stogdill, 1974; Yarwood, 1995). Therefore, many researchers have highlighted the importance of research on the use of humor by leaders (Decker \& Rotondo, 2001; Morreall, 1997). It should also be noted that an appropriate and moderate humor is one of the characteristics of effective teachers. Teachers with an advanced level of this skill reduce disciplinary problems and improve the sense of trust by making education entertaining (Cruickshank, Bainer, \& Metcalf, 1995).

Many studies have concluded that when humor is used positively, it strengthens positive feelings (Samson \& Gross, 2012), enables people to establish good relationships (Banas, Dunbar, Rodriguez, \& Liu, 2011; Özdemir, Sezgin, Kaya, \& Recepoğlu, 2011), enhances employees' motivation (Recepoğlu, Kılınç, \& Çepni, 2011), decreases organizational stress and alleviates the problems of employees (Malone, 1980), and improves production (Avolio, Howell, \& Sosik, 1999). The previous research dealing with the humor styles and humor usage of leaders reports that humor is an important factor influential on leadership processes (Benham, 1993; Bolinger, 2001; Cross, 1989; Franklin, 2008; Ellis, 1991; Hurren, 2001; Kent, 1993; Koonce, 1997; Phillips, 2000; Puderbaugh, 2006; Rahmani, 1994; Sala, 2000; Vickers, 2004; Williams, 1994; Williams \& Clouse, 1991; Ziegler, 1982; Ziegler \& Boardman, 1986). Researchers emphasize that humor has a positive effect on the solution of problems encountered in management, managing change, motivating followers, and exhibiting effective leadership behaviors.

Within the framework of humor theories, researchers have exerted effort to better understand and explain the nature of humor. Although a considerable amount of increase has occurred in the number of studies on humor in recent years, the number of studies on the relationship between leadership and humor style is scarce. According to the review of the related international literature, the concept of humor has been associated with humor in the workplace (Bradney, 1957; Caudron, 1992; Consalvo, 1989; Coser, 1959; Decker \& Rotondo, 1999; Duncan, 1982, 1984; Duncan \& Feisal, 1989; Duncan, Smeltzer, \& Leap, 1990; Dwyer, 1991; Goodchilds, 1959; Holmes, 2007; Holmes \& Marra, 2006; Murphy, 1986; Romero \& Cruthirds, 2006), organizational culture (Clouse \& Spurgeon, 1995; Fine \& De Soucey, 2005; Gunning, 2001; Holmes \& Marra, 2002; Lake, 2008; Linstead, 1985; Robert \& Yan, 2005), job satisfaction and burnout (Decker, 1987; Hurren, 2001, 2006; Mertz, 2000; Puderbaugh, 2006; Spurgeon, 1998), emotional intelligence (Teehan, 2006; Yip \& Martin, 2005), and 
leadership and organizational climate (Andersen, 1999; Arendt, 2006; Bateman, 2006; Benham, 1993; Bolinger, 2001; Cross, 1989; Davis \& Kleiner, 1989; Decker, 1986, 1987, 1991; Decker \& Rotondo, 2001; Ellis, 1991; Franklin, 2008; Hoffman, 2007; Kent, 1993; Koonce, 1997; Philbrick, 1989; Phillips, 2000; Priest \& Swain, 2002; Puderbaugh, 2006; Rahmani, 1994; Sala, 2000; Susa, 2002; Vecchio, Justin, \& Pearce, 2009; Vickers, 2004; Vinson, 2006; Vinton, 1989; Williams, 1994; Williams \& Clouse, 1991; Ziegler, 1982; Ziegler \& Boardman, 1986; Ziegler, Boardman, \& Thomas, 1985). Therefore, it is possible to argue that humor has been discussed in terms of various variables by many researchers, and that it has been tried to examine humor in a multifaceted manner.

The concept of humor has also been associated with coping with stress (Durmuş, 2000; Özdemir et al., 2011; Sümer, 2008; Yerlikaya, 2007), subjective well-being (İlhan, 2005; Tümkaya, 2011), marriage harmony (Fidanoğlu, 2006), learned resourcefulness level (Aslan, 2006), anger management styles (Soyaldın, 2007), interpersonal relationship styles (Erözkan, 2009), emotional well-being (Çetin, 2009), self-concept (Kahraman, 2009), problem-solving and self-respect (Traş, Arslan, \& Taş, 2011), stress, anxiety and depression (Yerlikaya, 2009), organizational health (Özdemir \& Recepoğlu, 2010), teaching leadership and organizational health (Recepoğlu, 2011), organizational climate (Küçükbayındır, 2003), job satisfaction and burnout (Karagöz, 2009; Küçükbayındır, 2003; Tümkaya, 2006a, 2006b), humor and academic achievement (Aydın, 2006; Çelik, 2006; Savaş, 2009; Topuz, 1995), and the development of the sense of humor among children (Akün, 1997). Neither the national literature nor the international literature contains any study investigating the relationship between humor and teacher leadership. This study, therefore, tried to shed some light on the relationship between teacher leadership and teacher sense of humor.

\section{Review of Literature}

\subsection{Humor}

Throughout the history, humor has attracted the attention of many philosophers, authors, and researchers from various disciplines such as philosophy, literature, sociology, education, and management. The number of studies on the construct has increased in recent years (Altinkurt \& Y1lmaz, 2011; Andersen, 1999; Avşar, 2008; Banas et al., 2011; Caudron, 1992; Consalvo, 1989; Davis \& Kleiner, 1989; Franklin, 2008; Holmes \& Marra, 2002, 2006; Küçükbayındır, 2003; Özdemir et al., 2011; Recepoğlu, 2011; Tümkaya, 2006a, 2006b, 2011). Some expressions that are frequently associated with the concept of "humor" in the daily life are "funny", "comic", "witty", "playful”, "humorous", "humorist", "jocular", and "joker". In this regard, humor, which is a social phenomenon (Martin, 2007), is an important element of social relations.

Based on the thesis of Hippocrates that the personality of a person is determined by the amount of certain liquids in the body, the concept of humor started to account for the state of mind in the course of time, was associated with pleasantness and cheerfulness indirectly, and finally started to be used in association with wit, joke, and ridicule (Martin, 2004). The Turkish equivalent of "humor" is mizah which comes from the Arabic word müzahî (Avşar, 
2008). The word mizah is described as "joke, quip" in the Ottoman History Idioms and Terms Dictionary (Pakalın, 1971). Arif Hikmet Par's Ottoman-Turkish Encyclopedic Dictionary defines it as the art of expressing thoughts and feelings by use of quip in an amusing manner (Par, 1990). Some sources identify the Arabic word mizah with the Turkish word gülmece (humor) (Avşar, 2008). Humor is defined as irony for entertaining, amusing, and kidding the behavior of somebody without hurting him/her; and as irony as a literary genre that reveals the ludicrous aspects of truth (Turkish Language Association [TLA], 2009). In the simplest sense, humor is part of comedy including wit, amusement, ridicule, mockery, irony, etc., and points to a laughing behavior about life and the faults of life (Ruch, 1998). According to Boysan (1990), humor is the art of human mind directly. Eroğlu (2008) expresses humor as the art of looking at and approaching life by smiling. According to Koestler (1997), humor is the only field of creative action where a stimulus of high complexity leads to a big reaction at the level of physiological reactions. Southam (2001) defines humor as a situation that generally results in laughter and smiling, takes place unexpectedly and suddenly, and involves astonishing elements.

The present study addressed principals' humor behaviors in five dimensions. The first dimension was sarcastic humor which is used for insulting, humiliating, hurting, and upsetting others. This humor style is adopted for setting bounds to relationships and acting superior. The second dimension was productive-social humor that allows producing humor and sharing it with others in order to improve relationships with others. In this humor type, jokes are made, and funny experiences are provided for others. The third dimension was appreciative humor. The appreciative humor refers to developing a positive attitude towards humor. The fourth dimension was rejective humor. The rejective humor means not accepting but rejecting humorous attitudes, discourses, and behaviors. The fifth dimension was non-humorous style. Those who have a non-humorous style rarely make jokes and use humor (Cemaloğlu et al., 2013).

\subsection{Teacher Leadership}

It is quite difficult to define leadership (Hoy \& Miskel, 1991). Every definition emphasizes a different aspect of leadership. Leadership is the sum of knowledge and skills of gathering a group of people around particular goals and putting them in action for accomplishing such goals (Çelik, 2000; Eren, 1991, 2003; Şişman, 2004). A leader, being a member of a cluster, is a person who has a positive influence on other members of the cluster. In other words, a leader is a member of an organization who has more positive influence on other members of the organization than they have on him/her (Başaran, 1998). The reconstruction of educational mentality and the transformations in school leadership have brought forward the concept of teacher leadership as an alternative to the single-man leadership that is traditionally based on chain of command, emphasizes one-way communication, and prevents division of responsibility. In this regard, teacher leadership has been intensely discussed within the context of school leadership in recent years (Beycioğlu \& Aslan, 2012; Can, 2009a, 2009b; Cranston, 2000; Frost \& Durant, 2003; Frost \& Harris, 2003; Harris \& Muijs, 2003, 2005; Helterbran, 2010; Lambert, 2003; Little, 2003; Muijs \& Harris, 2007).

Teacher leadership refers to expanding school leadership to include teachers, and requires 
teachers to contribute to school development by undertaking different leadership behaviors (Harris, 2003, 2005). Teacher leadership is also associated with teachers' learning continuously, contributing to the professional improvement of colleagues, and leading the activities aimed at improving teaching in school (Katzenmeyer \& Moller, 2009). According to Beycioğlu and Aslan (2012), teacher leadership is closely related to transforming school into a learning community for both employees and students, supporting the participation of teachers in teaching-related processes in school, and creating more democratic school environments. In parallel with that, it is argued that the concept of teacher leadership is based on the idea that teachers should have a central position in the processes of managing school effectively and improving learning and teaching (York-Barr \& Duke, 2004). Childs-Bowen, Moller and Scrivner (2000) define teacher leadership as affecting student learning positively, exerting effort to create higher-quality teaching practices, and ensuring the participation of other stakeholders of school in the school development process. According to Katzenmeyer and Moller (2009), among the main purposes of teacher leadership are to improve the teaching capacity of school, to create a more democratic school community, to authorize teachers, and to enhance teacher professionalism. Thus, it can be argued that teacher leadership is closely associated with improving the teaching conducted in school and classroom, increasing student learning, and creating a learning-focused culture in school.

Teacher leaders are expected to play different roles in school formally and informally (Beycioğlu \& Aslan, 2012). Harris (2002) reports that two primary roles which teacher leaders are expected to play are transfer role and mediation role. The transfer role refers to teacher leader, who is primarily responsible for the teaching conducted in the classroom, making his/her class internalize the principals for school development as well as the featured values and objectives of school, and acting as the leader of class. The mediation role points to teacher leaders' initiating discussions about the improvement of teaching in school and facilitating the collaboration process to take place between school administration and teachers or among teachers themselves. Conley (1997) suggests teacher leaders should mentor students and other teachers, contribute to the development of the curriculum implemented in school, follow the academic research carried out in their fields, and help other teachers continue their professional improvement. Katzenmeyer and Moller (2009) discuss the roles of teacher leaders in three dimensions: leading students and other teachers; leading operational processes in school; and leading decision-making processes. Accordingly, teacher leaders are expected to play such roles as the leader of students and other teachers, facilitator, coach, mentor, educator, curriculum expert, and team leader. Operational processes are those which are associated with the purposes that school serves. Therefore, teacher leaders may be expected to play such roles as action researcher and group leader in school. Finally, teacher leaders are expected to support the school development process, help school come into contact with other social organizations, and facilitate the processes of ensuring school-university and school-parents collaboration.

The present study examined the relationship between high school teachers' perceptions of school principals' humor styles and teacher leadership. The examination of the relationship between teachers' perceptions of school principals' humor styles and teacher leadership was considered significant for clarifying the humor style(s) of school principals with which 
teacher leadership was correlated. In addition, it was thought that making inferences about the relationship of teacher leadership and principal humor styles may contribute to the improvement of teacher leadership. Another point making the study significant was that the number of empirical studies about teacher leadership conducted in Turkey was limited (Beycioğlu \& Aslan, 2010, 2012; Can, 2009a, 2009b). Researchers argue that teacher leadership is influential on school development, improvement of student achievement and the quality of teaching conducted in school, and construction of school as a learning community (Harris, 2003; Harris \& Lambert, 2003; Harris \& Muijs, 2005; Katzenmeyer \& Moller, 2009). Thus, findings of studies in which the relationship between teacher leadership and different variables are examined may provide an important data source for policymakers and managers or administrators holding a decision-making position in order for teacher leadership, which is regarded as a potential power to increase student achievement (Frost \& Harris, 2003), to become more widespread and gain more strength in school. Thus, the present study made an attempt to answer the following questions.

1) What are high school teachers' perceptions of school principals' humor styles and teacher leadership?

2) Is there any significant relationship between high school teachers' perceptions of school principals' humor styles and teacher leadership?

3) Do the humor styles of high school principals predict the dimensions of teacher leadership significantly?

\section{Method}

\subsection{Research Design}

We made use of correlational research model to investigate the relationship between high school principals' humor styles and teachers' leadership behaviors. While the predicted variables of the study were the dimensions of teacher leadership (institutional improvement, professional improvement, and collaboration among colleagues), the predictive variables of the study were the humor styles employed by school principals (sarcastic, productive-social, appreciative, rejective, and non-humorous styles).

\subsection{Procedure and Participants}

A questionnaire with three parts was used to gather data in this study. The first part included the Personal Information Form addressing the demographic characteristics of participants such as gender, age, and total teaching experience. The second part comprised of "The Humor Behavior Scale" used for determining the humor behaviors of school principals, whereas the third part included "The Teacher Leadership Scale" to measure the leadership behaviors of teachers. The researcher distributed the questionnaires to high school teachers. Necessary instructions and explanations were printed at the beginning of the questionnaire, and teachers were asked to complete the questionnaires voluntarily. It was observed that each participant completed the questionnaire in about 10-12 minutes.

A total of 300 high school teachers were randomly selected from 12 high schools located in 
the city centre of Ankara, Turkey in 2013-2014 academic year. Out of these, 252 completed the questionnaire - a response rate of 84 percent. Therefore, the sample of this study included 252 teachers employed in 12 high schools in Ankara, Turkey and who responded to the items of the questionnaire voluntarily and anonymously.

The sample comprised of $113(44.8 \%)$ male and 139 (55.2\%) female teachers. $48(19.1 \%)$ were below the age of 30, $62(24.6 \%)$ were in the 30 to 35 age group, $59(23.4 \%)$ were in the 36 to 40 age group, and $83(32.9 \%)$ were over 40 years old; $108(42.9 \%)$ had a total of $1-5$ years of teaching experience, $81(32.1 \%)$ had a total of $6-10$ years of teaching experience and $63(25 \%)$ had a total of 11 years or more of teaching experience.

\subsection{Instrumentation}

The Humor Behavior Scale. This scale was developed by Cemaloğlu et al. (2013) to determine school principals' humor styles. The scale consisted of a total of 30 items under five dimensions titled sarcastic humor style, productive-social humor style, appreciative humor style, rejective humor style, and non-humorous style. It was a Likert-type scale answered on a rating scale from (1) "I strongly disagree" to (5) "I strongly agree." The percentages of variance explained by sarcastic, productive-social, appreciative, rejective, and non-humorous humor style components were 19.92, 18.22, 12.53, 10.53, and 8.89, respectively. These five humor style factors explained approximately 70.09 percent of the total variance. Factor loadings varied between .78 and .90 in the sarcastic humor style, between .63 and .87 in the productive-social humor style, between .68 and .82 in the appreciative humor style, between .62 and .80 in the rejective humor style, and finally between .73 and .82 in the non-humorous style. The internal consistency coefficient was found to be .92 for the entire scale, and .94 for the sarcastic humor style, .92 for the productive-social humor style, .86 for the appreciative humor style, .86 for the rejective humor style, and .90 for the non-humorous style (Cemaloğlu et al., 2013). In the present study, a reliability analysis was carried out over the final data gathered via the 30-item scale form. Results of the reliability analysis showed that the internal consistency coefficient was .81 for the entire scale, .38 for the sarcastic humor style, .85 for the productive-social humor style, .47 for the appreciative humor style, .73 for the rejective humor style, and .81 for the non-humorous style.

Teacher Leadership Scale. This Likert-type scale developed by Beycioğlu and Aslan (2010) consisted of 25 items under three dimensions named institutional improvement, professional improvement, and collaboration among colleagues. The scale items answered on a rating scale from 5 "Always" to 1 "Never" were gathered under three dimensions in terms of both perception and expectation. The institutional improvement component included 9 items, the professional improvement component contained 11 items, and the collaboration among colleagues dimension consisted of 5 items. Since the present study focused on the relationship between teachers' perceptions of school principals' humor styles and teacher leadership, only the perception part of the above-mentioned scale was used in the study. The total variance explained by these dimensions was $57.23 \%$. The item-total correlations of the scale items varied between .47 and .92. Beycioğlu and Aslan (2010) tested the reliability of the scale through internal consistency coefficient and test-retest methods. Accordingly, the 
internal consistency coefficient of the scale was found to be .95 . The internal consistency coefficient was found to be .87 for institutional improvement, .87 for professional improvement, and .92 for collaboration among colleagues. Furthermore, the researchers administered the scale to a group made up of teachers and administrators at two different times, and calculated the correlation coefficient between the scores obtained from both administrations. The results of the calculations (perception; $r=.87$ ) showed that the scale was reliable for use in the field. In the present study, internal consistency coefficient was calculated in order to determine the reliability of the scale. It was found to be .93 for the entire scale, .86 for institutional improvement, .76 for professional improvement, and .83 for collaboration among colleagues.

\subsection{Data Analysis}

The SPSS 15 package was used for data analysis. Data set was examined carefully, and defective and incorrect data were removed prior to analyses conducted in accordance with the research purposes. At the stage of analysis, arithmetic mean and standard deviation values related to dependent and independent variables were examined via the SPSS 15 package in the first place. Pearson product-moment correlation coefficients were calculated in order to determine the relationship between study variables. Then, multiple linear regression analysis was conducted in order to determine to what degree such dimensions of teacher leadership as institutional improvement, professional improvement, and collaboration among colleagues were predicted by perceived stress and teacher professionalism. Before the related analysis was made, it was examined whether each independent variable had a linear relationship with the dependent variable, and whether there was multicollinearity among independent variables. The analysis results showed that there was a linear relationship between independent variables and the dependent variable, but there was no relationship likely to pose a multicollinearity problem among independent variables.

\section{Findings}

4.1 The Means, Standard Deviations, and Correlation Coefficients among Variables for All High School Teachers

The means, standard deviations, and correlation coefficients among variables for all high school teachers participated in this study are given in Table 1.

As can be seen from Table 1, collaboration among colleagues component of teacher leadership was the highest rated $(\overline{\mathrm{X}}=3.98)$, whereas institutional improvement was the least $(\bar{X}=3.53)$. Furthermore, rejective humor style was rated at the highest level $(\bar{X}=4.19)$ by high school teachers while productive-social humor style was at the lowest level $(\bar{X}=2.90)$. 
Table 1. The correlations between the variables, and related mean and standard deviation values

\begin{tabular}{lcccccccccc}
\hline Variables & $\bar{X}$ & $S$ & 1 & 2 & 3 & 4 & 5 & 6 & 7 & 8 \\
\hline 1. II. & 3.53 & .73 & - & $.69^{* *}$ & $.62^{* *}$ & .00 & $.22^{* *}$ & .04 & .04 & -.03 \\
2. PI. & 3.74 & .76 & - & $.72^{* *}$ & -.07 & $.13^{*}$ & .03 & .11 & .00 \\
3. CAC. & 3.98 & .76 & & - & .05 & $.14^{*}$ & .06 & .07 & .07 \\
4. Sarcastic & 3.85 & .36 & & & - & -.09 & .01 & .08 & $.13^{*}$ \\
5. Productive-social & 2.90 & .76 & & & & - & $.50^{* *}$ & $.14^{*}$ & $.40^{* *}$ \\
6. Appreciative & 3.41 & .63 & & & & & - & $.27^{* *}$ & $.28^{* *}$ \\
7. Rejective & 4.19 & .71 & & & & & & - & $.42^{* *}$ \\
8. Non-humorous & 3.79 & .89 & & & & & & & - \\
\hline
\end{tabular}

Notes: $* p<.05, * * p<.01$

II. = Institutional improvement

PI. = Professional improvement

CAC. $=$ Collaboration among colleagues

As to the correlations in Table 1, although there were positive and significant relationships between productive-social humor style and institutional improvement $(r=.22, p<.01)$, professional improvement $(r=.13, p<.05)$, and collaboration among colleagues $(r=.14, p$ $<.05)$, other humor styles were not positively correlated with the dimensions of teacher leadership.

\subsection{Prediction of Institutional Improvement}

Table 2 presents the results of the regression analysis concerning the prediction of the institutional improvement dimension of teacher leadership.

Table 2. Regression analysis results concerning the prediction of institutional improvement

\begin{tabular}{lccccl}
\hline Variables & $\mathrm{B}$ & $\mathrm{SE}$ & $\beta$ & $t$ & $p$ \\
\hline Constant & 2.78 & .54 & & 5.14 & .00 \\
Sarcastic & .10 & .12 & .05 & .85 & .40 \\
Productive-social & .33 & .07 & .35 & 4.79 & .00 \\
Appreciative & -.13 & .08 & -.11 & -1.63 & .10 \\
Rejective & .10 & .07 & .10 & 1.49 & .14 \\
Non-humorous & -.15 & .06 & -.19 & -2.67 & .01 \\
\hline
\end{tabular}

$R=.29, R^{2}=.08, F(5,271)=4.93, p<.00$

As can be seen from Table 2, a multiple $R$ of .29 accounted for 8 percent of the variance in institutional improvement scores. Results indicated that productive-social humor style predicted the institutional improvement positively and significantly $(\beta=.35, p<.05)$, whereas non-humorous style predicted the institutional improvement negatively and significantly $(\beta=-.19, p<.05)$. Other humor styles did not predict institutional improvement significantly. 


\subsection{Prediction of Professional Improvement}

The results of the regression analysis regarding the prediction of the professional improvement dimension of teacher leadership are given in Table 3.

Table 3. Regression Analysis Results Concerning the Prediction of Professional Improvement

\begin{tabular}{lccccc}
\hline Variables & $\mathrm{B}$ & $\mathrm{SE}$ & $\beta$ & $t$ & $p$ \\
\hline Constant & 3.62 & .58 & & 6.25 & .00 \\
Sarcastic & -.11 & .13 & -.05 & -.88 & .38 \\
Productive-social & .18 & .07 & .18 & 2.45 & .02 \\
Appreciative & -.09 & .09 & -.08 & -1.08 & .28 \\
Rejective & .16 & .07 & .15 & 2.21 & .03 \\
Non-humorous & -.08 & .06 & -.10 & -1.37 & .17 \\
\hline$R$
\end{tabular}

$R=.20, R^{2}=.04, F(5,271)=2.27, p<.05$

For professional improvement, the regression analysis produces a multiple $R$ of .20 which explained 4 percent of the variance. The results of regression analysis indicated that the productive-social humor style $(\beta=.18, p<.05)$ and the rejective humor style $(\beta=.15, p<.05)$ predicted the professional improvement significantly. Nevertheless, other humor styles did not make a significant contribution to the equation of professional improvement.

\subsection{Prediction of Collaboration among Colleagues}

Table 4 demonstrates the results of the regression analysis concerning the prediction of the collaboration among colleagues dimension of teacher leadership.

Table 4. Regression Analysis Results Concerning the Prediction of Collaboration among Colleagues

\begin{tabular}{lccccc}
\hline Variables & $\mathrm{B}$ & $\mathrm{SE}$ & $\beta$ & $t$ & $p$ \\
\hline Constant & 2.97 & .56 & & 5.33 & .00 \\
Sarcastic & .14 & .12 & .07 & 1.12 & .26 \\
Productive-social & .14 & .07 & .14 & 1.92 & .06 \\
Appreciative & .00 & .08 & .00 & .04 & .97 \\
Rejective & .04 & .07 & .04 & .55 & .58 \\
Non-humorous & -.02 & .06 & -.03 & -.36 & .72 \\
\hline
\end{tabular}

$R=.15, R^{2}=.02, F(5,271)=1.26, p>.05$

According to the Table 4, sarcastic humor style, productive-social humor style, appreciative humor style, rejective humor style, and non-humorous style collectively did not have any significant relationship with the collaboration among colleagues component $(R=.15, p<.05)$. These variables explained only $2 \%$ of the variance in the scores of the collaboration among colleagues component. The results of regression analysis indicated that the sarcastic humor style $(\beta=.07, p>.05)$, the productive-social humor style $(\beta=.14, p>.05)$, the appreciative humor style $(\beta=.00, p>.05)$, the rejective humor style $(\beta=.04, p>.05)$, and the non-humorous style $(\beta=-.03, p>.05)$ did not predict the collaboration among colleagues significantly. 


\section{Discussion and Conclusion}

This study using humor styles as the predictors of teacher leadership has partially supported the hypothesis that school principals' humor styles are significant predictors of teacher leadership. Previous research on the humor styles and humor use of leaders reports, in parallel with the findings of the present study, that humor is both an important factor in school management and leadership (Cross, 1989; Ellis, 1991; Hurren, 2001; Kazarian \& Martin, 2004; Kent, 1993; Koonce, 1997; Özdemir \& Recepoğlu, 2010; Philbrick, 1989; Puderbaugh, 2006; Rahmani, 1994; Recepoğlu, 2011; Sala, 2000; Vickers, 2004; Williams \& Clouse, 1991; Ziegler, 1982). Previous studies also reveal that teacher leadership associated with humor is an important variable influential on the school development, the quality of teaching, and the improvement of student success (Harris, 2003; Harris \& Lambert, 2003; Harris \& Muijs, 2005; Katzenmeyer \& Moller, 2009).

Findings of this study indicated that the teacher leadership dimension which the teachers rated the highest was the collaboration among colleagues, while the dimension in which the teachers had lowest-level perception was the institutional improvement. In other words, participant teachers displayed institutional improvement-related behaviors less. Institutional improvement component of teacher leadership refers more to teachers' out-of-classroom practices directed to school improvement (Katzenmeyer \& Moller, 2009). Therefore, this finding probably suggests that teachers do not perceive school-wide leadership behaviors to be within their job descriptions. This finding may also denote that teachers primarily focus on developing effective classroom practices and therefore give more importance to collaborate with colleagues. In parallel with the findings of the present study, Kılınç and Recepoğlu (2013) reported that teachers attached the lowest value on institutional improvement on the part of perception. As distinct from the findings of the present study, Kılınç and Recepoğlu (2013) showed that professional improvement was the dimension in which teachers had the highest perception level. On the other hand, Beycioğlu and Aslan (2012) demonstrated that professional improvement was the dimension in which teachers had the highest perception level while collaboration among colleagues was the dimension in which teachers had the lowest perception level.

Findings revealed that teachers had highest-level perception regarding principals' humor behaviors in the rejective humor style while they had the lowest-level perception in the productive-social humor style. This finding reveals that school principals mostly tend to avoid humorous attitudes, discourses, and behaviors in schools. However, this finding is not consistent with the research findings provided by Kent (1993), Koonce (1997), Mertz (2000), Özdemir and Recepoğlu (2010), Phillips (2000), Puderbaugh (2006), Recepoğlu (2011), Recepoğlu, Kılınç and Çepni, (2011), Spurgeon (1998), and Williams (1994). According to the findings of these studies, teachers had the highest-level perception in the productive humor style of school principals.

Results showed that the only significant relationship among study variables was between the productive-social humor style and institutional improvement, professional improvement, and collaboration among colleagues components of teacher leadership. Other humor styles were not significantly related to teacher leadership dimensions. This finding suggests that teachers 
perceive leadership roles more positively when they work with school principals employing productive-social humor. As the productive-social humor takes humor-production as basis for developing relationships with others, and allows sharing the produced humor with colleagues (Cemaloğlu et al., 2013), it is reasonable to suggest that school principals may build positive relationships and effective communication among colleagues by employing productive-social humor which probably encourages teachers to assume leadership roles in and out of classroom.

The only significant predictor of institutional improvement and professional improvement components of teacher leadership was school principals' productive-social humor style. This finding refers that productive-social humor style is an important construct that should be given importance in the process of school improvement and teachers' professional improvement. Institutional improvement refers to teachers' participating in school-wide instructional practices such as building a school vision, designing effective strategic school plans, and collaborating with parents (Beycioğlu \& Aslan, 2010; Katzenmeyer \& Moller, 2009; York-Barr \& Duke, 2004). This finding, therefore, suggests that school principals may support professional development of teachers and may make use of teachers' expertise and knowledge to improve institutional capacity of school. Results provided by Kent (1993) indicated that principals having the productive style were the most effective ones according to the perceptions of school teachers. Kent concluded that the humor style of principal was an important factor influential on the evaluation of effectiveness of principals by teachers (Kent, 1993). Furthermore, another study reported that there was a significant relationship between the humor styles of principals and leader effectiveness according to the perceptions of teachers (Vickers, 2004).

This study was conducted to examine the perceptions of teachers on school principals' humor styles and teacher leadership. Thus, only teachers answered the items of the scale. Future studies, therefore, should focus on examining the relationship between school principals' perceptions of their own humor styles and teachers' leadership behaviors and roles. The present study was a cross-sectional one employing survey model. Therefore, a longitudinal examination the relationship of humor styles of school principals and teacher leadership may be useful to better understand the role of the construct of humor in teachers' leadership behaviors. This study performed multiple linear regression to predict teacher leadership from teachers' perceptions of humor styles. Therefore, the correlations and predictive relationships between humor styles and teacher leadership were taken into account. Further studies may examine the causal relationships among these variables. Depending on the result of the current study, it is suggested that principals participate in various educational programs for improving and effectively using their humor styles to encourage teacher leadership. School principals may use humor for making school an environment to which students and teachers come fondly and willingly by making school a cheerful and attractive learning environment and creating a climate that encourages students to develop positive behaviors. Moreover, school principals may encourage the use of humor by preparing a healthy environment for teachers to exhibit humor behaviors. In consideration of the relationship between humor use and teacher leadership, the power of humor may be used for improving teacher leadership. 
Results of this study may well be used by school principals and teachers to prepare a healthy school environment which nourishes teachers' undertaking leadership roles and behaviors. Teacher and school principal training programs may also concentrate more on humor behaviors which have a potential to develop teacher leadership.

\section{References}

Akün, D. (1997). 9-11 yaş çocuklarında mizah duygusunun gelişimi [The development of humor in children of 9-11 years old] (Unpublished master thesis). Marmara University, İstanbul, Turkey.

Altınkurt, Y., \& Y1lmaz, K. (2011). İlköğretim okulu öğretmenlerinin mizah tarzları [Humor styles of primary school teachers]. Pegem Journal of Education and Instruction, 1(2), 1-8.

Andersen, H. A. (1999). Self-perceived use of humor by leaders in nonprofit organizations (Unpublished doctoral dissertation). Retrieved from ProQuest Dissertations and Theses database. (UMI No. 9962113)

Arendt, L. A. (2006). Leaders' use of positive humor: Effects on followers' self-efficacy and creative performance (Unpublished doctoral dissertation). Retrieved from ProQuest Dissertations and Theses database. (UMI No. 3231493)

Aslan, H. (2006). Ortaögretim kurumlarında görev yapan ögretmenlerin öğrenilmiş güçlülük düzeyleri ve cinsiyetlerine göre mizah tarzlarının incelenmesi [Investigating the humor styles of teachers who work in secondary education schools according to their level of learned resourcefulness and their gender] (Unpublished master thesis). Çukurova University, Adana, Turkey.

Avolio, B. J., Howell, J. M., \& Sosik, J. J. (1999). A funny thing happened on the way to the bottom line: Humor as a moderator of leadership style effects. Academy of Management Journal, 42(2), 219-228.

Avşar, V. (2008). Öğretmen adaylarının mizah tarzları ve cinsiyet rolleri ilişkisi [The relationship between humor styles and sex-role of teacher candidates] (Unpublished master thesis). Marmara University, İstanbul, Turkey.

Aydın, İ. S. (2006). Türkçe derslerinde mizah kullanımının öğrenci tutum ve başarısına etkisi [The effects of the use of humor on student attitude and achievement in Turkish courses (in the sample of İzmir 8th grade students)] (Unpublished doctoral dissertation). Dokuz Eylül University, İzmir, Turkey.

Banas, J. A., Dunbar, N., Rodriguez, D., \& Liu, S. J. (2011). A review of humor in educational settings: Four decades of research. Communication Education, 60(1), 115-144. http://dx.doi.org/10.1080/03634523.2010.496867

Barbour, G. (1998). Want to be a successful manager? Now that's a laughing matter. Public Management, 80(7), 6-9. 
Başaran, İ. E. (1998). Yönetimde insan ilişkileri. Yönetsel davranış [Human relationships in management. Organizational behavior]. Ankara: Nobel.

Bass, B. M. (1990). Bass and Stodgill's handbook of leadership: Theory, research and managerial applications. New York: Free.

Bateman, W. K. (2006). The relationship between a sense of humor and situational leadership styles, flexibility and effectiveness (Doctoral dissertation). Retrieved from ProQuest Dissertations and Theses database. (UMI No. 3244422)

Benham, K. (1993). The relationship of leadership style, change and use of humor in health care executives (Doctoral dissertation). Retrieved from ProQuest Dissertations and Theses database. (UMI No. 9324822)

Beycioğlu. K., \& Aslan. B. (2010). Öğretmen liderliği ölçeği: Geçerlik ve güvenirlik çalışması [Teacher leadership scale: A validity and reliability study]. Elementary Education Online, 9(2), 764-775.

Beycioğlu. K., \& Aslan. B. (2012). Öğretmen ve yöneticilerin öğretmen liderliğine ilişkin görüşleri: Bir karma yöntem çalışması [Teachers and administrators' views on teacher leadership: A mixed methods study]. Educational Administration: Theory and Practice, $18(2), 191-223$.

Bolinger, B. S. (2001). Humor and leadership: A gender-based investifation of correlation between the attribute of humor and effective leadership (Unpublished Doctoral dissertation). Retrieved from ProQuest Dissertations and Theses database. (UMI No. 9324822)

Boysan, A. (1990). Paldır güldür mizah söyleşileri (3rd ed.). İstanbul: Bas.

Bradney, P. (1957). The joking relationship in industry. Human Relations, 10, 179-187.

Can. N. (2009a). Öğretmen liderliği [Teacher leadership]. Ankara: Pegem Akademi.

Can. N. (2009b). Öğretmenlerin sınıfta ve okulda liderlik davranışları [Leadership behaviors of teachers in classroom and school]. University of Gaziantep Journal of Social Sciences, 2, 385-399.

Caudron, S. (1992). Humor is healthy in the workplace. Personnel Journal, 71(6), 63-68.

Çelik, E. (2006). Fizik ögrretiminde bilgisayar destekli mizahın ögrenci başarısına ve tutumuna etkisi [The effect of the computer-assisted humor on the students academic achievement and attitudes towards physics course]. (Unpublished master thesis). Ankara University, Ankara, Turkey.

Çelik, V. (2000). Eğitimsel liderlik [Educational leadership]. Ankara: Pegem A.

Cemaloğlu, N., Recepoğlu. E., Şahin. F., Daşçı. E., \& Köktürk, O. (2012). Mizah davranışları ölçeğinin geliştirilmesi: Geçerlik ve güvenirlik çalışması [Developing humor behavior scale: The study of validity and reliability]. Journal of Turkish Educational Science, 
10(4), 694-716.

Çetin, M. (2009). Çalışanların mizah tarzlarının işe ilişkin duygusal iyilik algıları üzerine etkisi ve sosyal iklimin bu ilişki üzerindeki şartl değişken rolü [The relationship between humor styles and job related affective well - being of employees among different sectors and the moderating effect of social climate] (Unpublished master thesis). Marmara University, İstanbul, Turkey.

Childs-Bowen. D., Moller. G., \& Scrivner, J. (2000). Principals: Leaders of leaders. NASSP Bulletin, 84, 27-34.

Clouse, R. W., \& Spurgeon, K. L. (1995). Corporate analysis of humor. Psychology - A Journal of Human Behaviour, 32(3-4), 1-24.

Conger, J. A. (1989). The charismatic leader: Beyond the mystique of exceptional leadership. San Francisco CA: Jossey-Bass.

Conley, D. T. (1997). Roadmap to restructuring: Charting the course of change in American education. Eugene, OR: ERIC Clearinghouse on Educational Management.

Consalvo, C. (1989). Humor in management: No laughing matter. Humor: International Journal of Humor Research, 2(3), 285-297. http://dx.doi.org/10.1515/humr.1989.2.3.285

Coser, R. L. (1959). Some social functions of laughter: A study of humor in a hospital setting. Human Relations, 12(2), 171-182. http://dx.doi.org/10.1177/001872675901200205

Cranston, N. C. (2000). Teachers as leaders: A critical agenda for the new millennium. Asia-Pacific Journal of Teacher Education, 28(2), 123-131. http://dx.doi.org/10.1080/713650688

Cross, M. (1989). Leadership perceptions: The role of humor (Doctoral dissertation). Retrieved from ProQuest Dissertations and Theses database. (UMI No. 9019774)

Cruickshank, D. L., Bainer, D. L., \& Metcalf, K. K. (1995). The act of teaching. New York: McGraw-Hill.

Csikszentmihalyi, M., \& McCormack, J. (1986). The influence of teachers. Phi Delta Kappan, 67, 415-419.

Davis, A., \& Kleiner, B. (1989). The value of humor in effective leadership. Leadership and Organization Development Journal, 10(1), 1-3.

Decker, W. H. (1986). Sex conflict and impressions of managers' aggressive humor. The Psychological Record, 36(4), 483-490.

Decker, W. H. (1987). Managerial humor and subordinate satisfaction. Social Behavior and Personality: An International Journal, 15, 225-232.

Decker, W. H. (1991). Style, gender, and humor effects in evaluating leaders. The Mid Atlantic Journal of Business, 27(2), 117. 
Decker, W. H., \& Rotondo, D. M. (1999). Use of humor at work: Predictors and implications. Psychological Reports, 84(3), 961-968. http://dx.doi.org/10.2466/pr0.1999.84.3.961

Decker, W. H., \& Rotondo, D. M. (2001). Relationships among gender, type of humor and perceived leader effectiveness. Journal of Managerial Issues, 13(4), 450-465.

Duncan, W. J. (1982). Humor in management: Prospects for administrative practice and research. Academy of Management Review, 7(1), 136-142.

Duncan, W. J. (1984). Perceived humor and social network patterns in a sample of task-oriented groups: A reexamination of prior research. Human Relations, 27(11), 895-907. http://dx.doi.org/10.1177/001872678403701102

Duncan, W. J., \& Feisal, J. P. (1989). No laughing matter: Patterns of humor in the workplace. Organizational Dynamics, 17(4), 18-30. http://dx.doi.org/10.1016/S00902616(89) 80024-5

Duncan, W., Smeltzer, L., \& Leap, T. (1990). Humor and work: Applications of joking behavior to management. Journal of Management, 16(2), 255-276. http://dx.doi.org/10.1177/014920639001600203

Durmuş, Y. (2000). Mizah duygusu ile başaçıkma stratejileri arasındaki ilişki [The relationship between sense of humor and coping strategies] (Unpublished master thesis]. Middle East Technical University, Ankara, Turkey.

Dwyer, T. (1991). Humor, power and change in organizations. Human Relations, 44(1), 1-19. http://dx.doi.org/10.1177/001872679104400101

Ellis, A. (1991). The relationship between nursing education administrator's use of humor and their leadership effectiveness as perceived by faculty (Unpublished doctoral dissertation). Retrieved from ProQuest Dissertations and Theses database. (UMI No. 9218005)

Eren, E. (1991). Yönetim ve organizasyon [Management and organization]. İstanbul: İstanbul University Faculty of Business.

Eren, E. (2003). Yönetim ve organizasyon: Çağdaş ve küresel yaklaşımlar [Management and organization: Modern and global approaches]. İstanbul: Beta.

Eroğlu, E. (2008). Muzaffer İzgü'nün çocuk kitaplarının mizah unsurları yönüyle incelenmesi [Analysis of Muzaffer İzgü's children books in terms of humour elements] (Unpublished master thesis). Abant İzzet Baysal University, Bolu, Turkey.

Erözkan, A. (2009). Üniversite öğrencilerinin kişiler arası ilişki tarzları ve mizah tarzları [Interpersonal relationship styles and humour styles of university students]. Dokuz Eylül University, Journal of Buca Faculty of Education, 26, 56-66.

Farrell, L. (1998). You've got to be kidding: Humor as a fundamental management tool. Records Management Quarterly, 32(3), 3-8.

Fidanoğlu, O. (2006). Evlilik uyumu, mizah tarzı ve kaygı düzeyi arasındaki ilişki [The relationship among marital adjustment, humor style and anxiety] (Unpublished master 
thesis). Marmara University, İstanbul, Turkey.

Fine, G. A., \& De Soucey, M. (2005). Joking cultures: Humor themes as social regulation in group life. Humor: International Journal of Humor Research, 18(1), 1-22. http://dx.doi.org/10.1515/humr.2005.18.1.1

Firestone, W. A., \& Rosenblum, S. (1988). Building commitment in urban high schools. Educational Evaluation and Policy Analysis, 10, 285-299. http://dx.doi.org/10.3102/01623737010004285

Franklin, D. D. (2008) Do leaders use more humor (Unpublished doctoral dissertation). Retrieved from ProQuest Dissertations and Theses database. (UMI No. 3304476)

Frost. D., \& Durrant. J. (2003). Teacher leadership: Rationale, strategy and impact. School Leadership \& Management, 23(2), 173-186. http://dx.doi.org/10.1080/13632430320000 91940

Frost. D., \& Harris, A. (2003). Teacher leadership: Towards a research agenda. Cambridge Journal of Education, 33(3), 479-498. http://dx.doi.org/10.1080/0305764032000122078

Goodchilds, J. D. (1959). Effects of being witty on position in the social structure of a small group. Sociometry, 22(3), 261-272.

Gruner, C. (1997). The game of humor: A comprehensive theory of why we laugh. New Brunswick, NJ: Transaction.

Gunning, B. L. (2001). The role that humor plays in shaping organizational culture (Unpublished doctoral dissertation). Retrieved from ProQuest Dissertations and Theses database. (UMI No. 3036377)

Harris, A. (2002). School improvement: What's in it for schools? London: RoutledgeFalmer.

Harris, A. (2003). Teacher leadership as distributed leadership: Heresy, fantasy or possibility? School Leadership \& Management, 23(3), 313-324. http://dx.doi.org/10.1080/1363243032000112801

Harris, A. (2005). Teacher leadership: More than just a feel-good factor? Leadership and Policy in Schools, 4(3), 201-219. http://dx.doi.org/10.1080/15700760500244777

Harris, A., \& Lambert, L. (2003). Building leadership capacity for school improvement. Maidenhead, Philadelphia: Open University.

Harris, A., \& Muijs, D. (2003). Teacher leadership: Principles and practice. London: National College for School Leadership. Retrieved January 11, 2012 from ehttp://www.nationalcollege.org.uk/index/docinfo.htm?id=17417

Harris, A., \& Muijs, D. (2005). Improving schools through teacher leadership. Maidenhead, Philadelphia: Open University.

Helterbran, V. R. (2010). Teacher leadership. Overcoming "I'm just a teacher" syndrome. Education, 131(2), 363-371. 
Hoffman, M. (2007). Does sense of humor moderate the relationship between leadership style and conflict management style? (Unpublished doctoral dissertation). Retrieved from ProQuest Dissertations and Theses database. (UMI No. 3284029)

Hogan, R., Curphy, G. J., \& Hogan, J. (1994). What we know about leadership: Effectiveness and personality. American Psychologist, 49(6), 493-504. http://dx.doi.org/10.1037/1089-2680.9.2.169

Holmes, J. (2007). Humour and the construction of Maori leadership at work. Leadership, 3(1), 5-27. http://dx.doi.org/10.1177/1742715007073061

Holmes, J., \& Marra, M. (2002). Having a laugh at work: How humour contributes to workplace culture. Journal of Pragmatics, 34(12), 1683-1710. http://dx.doi.org/10.1016/S0378-2166(02)00032-2

Holmes, J., \& Marra, M. (2006). Humor and leadership style. Humor: International Journal of Humor Research, 19(2), 119-138. http://dx.doi.org/10.1515/HUMOR.2006.006

Hoy, W. K., \& Miskel, C. G. (1991). Educational administration theory, research, and practice (4th ed.). New York: McGraw-Hill.

Hurren, B. L. (2001). The effects of principals' humor on teacher's job satisfaction (Unpublished doctoral dissertation). Retrieved from ProQuest Dissertations and Theses database. (UMI No. 3042753)

Hurren, B. L. (2006). The effects of principals' humor on teacher's job satisfaction. Educational Studies, 32(4), 373-385. http://dx.doi.org/10.1080/03055690600850321

İlhan, T. (2005). Öznel iyi oluşa dayalı mizah tarzları modeli [A model of humor styles based on subjective well-being] (Unpublished master thesis). Gazi University, Ankara, Turkey.

Kahn, W. (1989). Toward a sense of organizational humor: Implications for organizational diagnosis and change. The Journal of Applied Behavioral Science, 25(1), 45-63. http://dx.doi.org/10.1177/0021886389251004

Kahraman, H. (2009). Yatılı ilköğretim bölge okulu ve normal okullara devam eden ergenlerde mizah duygusu ile benlik algisı arasındaki ilişkinin incelenmesi [Examining perception of teachers and students at elementary boarding district school in borders of adana province with respect to the quality of school life] (Unpublished master thesis). Selçuk University, Konya, Turkey.

Karagöz, O. (2009). İlköğretim Türkçe öğretmenlerinin mizah tarzlarl ile tükenmişlik düzeyleri arasındaki ilişki [The relationship between primary schools Turkish teachers humour style and their burnout] (Unpublished master thesis). Maltepe University, İstanbul, Turkey.

Katzenmeyer, M., \& Moller, G. (2009). Awakening the sleeping giant. Helping teachers develop as leaders (3rd ed.). Thousand Oaks, California: Corwin.

Kazarian, S. S., \& Martin, R. A. (2004). Humor styles, personality and well-being among 
Lebanese university students. European Journal of Personality, 18, 209-219. http://dx.doi.org/10.1002/per.505

Kent, S. H. (1993). An investigation of the relationship between humor style and effectiveness of elementary school principals as perceived by teachers in Georgia. (Unpublished doctoral dissertation). Retrieved from ProQuest Dissertations and Theses database. (UMI No. 9416267).

Koestler, A. (1997). Mizah yaratma eylemi [Action of producing humor] (Trans. S. Kabakçığlu \& Ö. Kabakçığlu) İstanbul: İris.

Koonce, W. J. (1997). The relationship between principals' humor styles and school climate in elementary schools (Unpublished doctoral dissertation). Retrieved from ProQuest Dissertations and Theses database. (UMI No. 9731494)

Küçükbayındır, Z. (2003). The effect of humour training on job satisfaction and organizational climate (Unpublished master thesis). Marmara University, İstanbul, Turkey.

Lake, E. (2008). Leading with humor: A quantitative, correlational study of humor styles and organizational culture (Unpublished doctoral dissertation). Retrieved from ProQuest Dissertations and Theses database. (UMI No. 3313925)

Lambert, L. (2003). Leadership capacity for lasting school improvement. Alexandria, Virginia: Association for Supervision and Curriculum Development.

Leithwood, K., \& Jantzi, D. (2000). Principal and teacher leadership effects: A replication. School Leadership \& Management, 20(4), 415-434. http://dx.doi.org/10.1080/713696963.

Linstead, S. (1985). Jokers wild: The importance of humour in the maintenance of $\begin{array}{lllll}\text { organizational culture. } & \text { Sociological Review, 33(4), }\end{array}$ http://dx.doi.org/10.1111/j.1467-954X.1985.tb02447.x

Little, J. W. (2003). Constructions of teacher leadership in three periods of policy and reform activism. School Leadership \& Management, 23(4), 401-419. http://dx.doi.org/10.1080/1363243032000150944

Malone, P. B. (1980). Humor: A double-edged tool for today's managers? Academy of Management Review, 5(3), 357-360.

Martin, R. A. (2004). Sense of humor and physical health: Theoretical issues recent findings, and future directions. Humor: International Journal of Humor Research, 17(1-2), 1-19.

Martin, R. A. (2007). The psychology of humor: An integrative approach. San Diego, CA: Elsevier Academic.

Mertz, D. J. C. (2000). Teachers' perceptions of principals' humor style: Its effect on teacher satisfaction and burnout (Unpublished doctoral dissertation). Retrieved from ProQuest Dissertations and Theses database. (UMI No. 9991715) 
Morreall, J. (1997). Gülmeyi ciddiye almak [Taking laughing seriously] (Trans. K. Aysevener \& Ş. Soyer). İstanbul: İris.

Muijs, D., \& Harris, A. (2007). Teacher leadership in (in) action. Three case studies of contrasting schools. Educational Management Administration \& Leadership, 35(1), 111-134.

Murphy, M. (1986). The functions of humor in the workplace (Unpublished doctoral dissertation). Retrieved from ProQuest Dissertations and Theses database. (UMI No. 3035633050)

Özdemir, S., \& Recepoğlu, E. (2010). Örgütsel sağllk ve mizah [Organizational health and humor]. Proceedings of 5. National Congress of Educational Administration, May 01-02 2010, Antalya, Turkey.

Özdemir, S., Sezgin, F., Kaya, Z., \& Recepoğlu, E. (2011). İlköğretim okulu öğretmenlerinin stresle başa çıkma tarzları ile kullandıkları mizah tarzları arasındaki ilişki [The relationship between primary school teachers' coping styles with stress and humor styles]. Educational Administration: Theory and Practice, 17(3), 405-428.

Pakalın, M. Z. (1971). Osmanlı tarih deyimleri ve terimleri sözlüğ̈̈ [Dictionary of Ottoman history idioms and terms]. İstanbul: Ministry of National Education.

Par, A. H. (1990). Osmanlıca-Türkçe ansiklopedik sözlük [Ottoman Turkish-Turkish encyclopedic dictionary]. İstanbul: Serhat.

Philbrick, K. T. (1989). The use of humor and effective leadership styles (Unpublished doctoral dissertation). Retrieved from ProQuest Dissertations and Theses database. (UMI No. 9021898)

Phillips, K. A. (2000). The use of humor and effective leadership styles by elementary principals in central Florida (Unpublished doctoral dissertation). Retrieved from ProQuest Dissertations and Theses database. (UMI No.9977824)

Priest, R. F., \& Swain, J. E. (2002). Humor and its implications for leadership effectiveness. Humor: International Journal of Humor Research, 15(2), 169-189. http://dx.doi.org/10.1515/humr.2002.010

Puderbaugh, A. (2006). The relationship between supervisor's humor styles and subordinate job satisfaction. (Unpublished doctoral dissertation). Retrieved from ProQuest Dissertations and Theses database. (UMI No. 3208068)

Rahmani, L. (1994). Humor styles and managerial effectiveness (Doctoral dissertation, University of LaVerne, 1992). Dissertation Abstracts International, 55(5), 1161.

Recepoğlu, E. (2011). Öğretmen algılarına göre okul müdürlerinin mizah tarzları ile öğretim liderliği davranışlarl ve okulun örgütsel sağlı̆̆l arasındaki ilişki [The relationship between principals humor styles and both instructional leadership behaviours and organizational health of the school] (Unpublished doctoral dissertation). Gazi University, 
Ankara, Turkey.

Recepoğlu, E., Kılınç, A. Ç., \& Çepni, O. (2011). Examining teachers' motivation level according to school principals' humor styles. Educational Research and Reviews, 6(17), 928-934.

Recepoğlu. E., \& Kılınç, A. Ç. (2013). Ortaöğretim okulu öğretmenlerin öğretmen liderliğine ilişkin alg1 ve beklentilerine yönelik bir inceleme [An inquiry into high school teachers' perceptions on and expectations from teacher leadership]. Kalem International Journal of Educational and Human Sciences, 3(2), 175-215.

Robert, C., \& Yan, W. (2005, August). Why would a duck walk into a bar? A theoretical examination of humor and culture in organizations. Paper presented at the meeting of the Academy of Management, Honolulu, HI.

Romero, E. J., \& Cruthirds, K. W. (2006). The use of humor in the workplace. Academy of Management Perspectives, 20(2), 58-69.

Ruch, W. (1998). Sense of humor: A new look at an old concept. In W. Ruch (Ed.), The sense of humor: Explorations of a personality characteristic (pp. 3-14). Berlin, Germany: Mouton de Gruyter.

Safferstone, M. J. (1999). Did you hear the one about...? Leading with humor pay dividends. Academy of Management Executive, 13(4), 103-104.

Sala, F. (2000). Relationship between executives' spontaneous use of humor and effective leadership (Unpublished doctoral dissertation). Retrieved from ProQuest Dissertations and Theses database. (UMI No. 9965659)

Samson, A. C., \& Gross, J. J. (2012). Humour as emotion regulation: The differential consequences of negative versus positive humour. Cognition \& Emotion, 26(2), 375-384. http://dx.doi.org/10.1080/02699931.2011.585069

Savaş, S. (2009). İlköğretim 7. sınıf Türkçe derslerinde mizah kullanımının öğrenci tutum ve başarisına etkisi [The effects of the use of humor at seventh grade on student attitude and achievement in Turkish courses (Unpublished master thesis). Zonguldak Karaelmas University, Zonguldak, Turkey.

Shamir, B. (1995). Social distance and charisma: Theoretical notes and an exploratory study. Leadership Quarterly, 6(1), 19-48. http://dx.doi.org/10.1016/1048-9843(95)90003-9

Şişman, M. (2004). Ö̆gretim liderliği [Instructional leadership] (2.ed.). Ankara: Pegem A.

Southam, M. A. (2001). The use of humor by occupational therapists to promote adaptation in their adult clients with physical disabilities (Unpublished doctoral dissertation). Retrieved from ProQuest Dissertations and Theses database. (UMI No. 304765430)

Soyaldın, S. Z. (2007). Orta ögrretim ögrencilerinin öfke ifade tarzları ile mizah tarzları arasındaki ilişkinin incelenmesi. [The relationships between anger expression styles and humor styles among secondary school students] (Unpublished master thesis). Mersin University, Mersin, Turkey. 
Spurgeon, K. (1998). Humor versus burnout: An organizational analysis of principals and teachers (Unpublished doctoral dissertation). Retrieved from ProQuest Dissertations and Theses database. (UMI No. 9831984)

Stogdill, R. M. (1974). Handbook of leadership: A survey of the literature. New York: Free.

Sümer, M. (2008). Okul öncesi öğretmenliği öğrencilerinin stresle başa çıkma stilleri ve bazı değişkenlere göre mizah tarzlarının karşılaştırılması [Pre-school teaching student's styles of coping with stress and the comparison of their manners of humor in accordance with various variable] (Unpublished master thesis]. Selçuk University, Konya, Turkey.

Susa, A. M. (2002). Humor type, organizational climate, and the outcomes: The shortest distance between an organization's environment and the bottom line is laughter (Unpublished doctoral dissertation). Retrieved from ProQuest Dissertations and Theses database. (UMI No. 3074105)

Teehan, R. E. (2006). The relationship between emotional intelligence, sense of humor and job satisfaction in masters of business students at a Midwestern University (Unpublished doctoral dissertation). Retrieved from ProQuest Dissertations and Theses database. (UMI No. 3215971).

TLA [Turkish Language Association] (2009). Gülmece. Retrieved March 17, 2012 from ttp://tdkterim.gov.tr/ bts/?kategori=ver itbn\&kelimesec $=143826$

Topuz, S. (1995). Popülerlik, mizah duygusu ve akademik başarı arasındaki ilişki [The relationships among popularity, sense of humor and academic achievement] (Unpublished master thesis). Middle East Technical University, Ankara, Turkey.

Traş, Z., Arslan, C., \& Taş, A. M. (2011). Öğretmen adaylarında mizah tarzları, problem çözme ve benlik saygisının incelenmesi [Analysis of humor styles, problem solving and selfesteem of prospective teachers]. International Journal of Human Sciences, 8(2), 716-732.

Tümkaya, S. (2006a). Öğretim elemanlarının mizah tarzları ve mizahı yordayıcı değişkenler [Humor styles of university lecturers and variables that predict humor]. Eurasian Journal of Educational Research, 23, 200-208.

Tümkaya, S. (2006b). İş ortamı ve mizah yoluyla başa çıkmanın öğretim elemanlarındaki tükenmişlikle ilişkisi [Faculty burnout in relation to work environment and humor as a coping strategy]. Educational Sciences: Theory and Practice, 6(3), 889-910.

Tümkaya, S. (2011). Humor styles and socio-demographic variables as predictors of subjective well-being of Turkish university students. Education and Science, 36(160), 158-170.

Vecchio, R. P., Justin, J. E., \& Pearce, C. L. (2009). The influence of leader humor on relationships between leader behavior and follower outcomes. Journal of Managerial Issues, 21(2), 171-194.

Vickers, P. C. (2004). The use of humor as a leadership tool by Florida public school principals (Unpublished doctoral dissertation). Retrieved from ProQuest Dissertations and Theses 
database. (UMI No. 3144895)

Vinson, G. A. (2006). Aggressive humor and workplace leadership: Investigating the types and outcomes of workplace leaders' aggressive humor (Unpublished doctoral dissertation). Retrieved from ProQuest Dissertations and Theses database. (UMI No. 3220044)

Vinton, K. (1989). Situational leadership theory: An examination of a prescriptive theory. Journal of Applied Psychology, 72(3), 444-451.

Williams, R. A. (1994). The perceived value of administrator humor to school climate (Unpublished doctoral dissertation). Retrieved from ProQuest Dissertations and Theses database. (UMI No. 9429737)

Williams, R. A., \& Clouse, R. W. (1991). Humor as a management technique: Its impact on school culture and climate. Report No. EA 023388 (Nashville, TN, Metropolitan Nashville-Davidson County Schools) (ERIC Document Reproduction Service No. ED $337866)$.

Yarwood, D. L. (1995). Humor and administration: A serious inquiry into unofficial organizational communication. Public Administration Review, 55(1), 81-90.

Yerlikaya, E. (2009). Üniversite ögrencilerinin mizah tarzları ile algllanan stres, kaygl ve depresyon düzeyleri arasındaki ilişkinin incelenmesi (Unpublished master thesis). Çukurova University, Adana, Turkey.

Yerlikaya, N. (2007). Lise öğrencilerinin mizah tarzları ile stresle başaçıkma tarzlarıarasındaki ilişkinin incelenmesi [The relationship between humor styles and coping styles of high school students] (Unpublished master thesis). Çukurova University, Adana, Turkey.

Yip, J. A., \& Martin, R. A. (2005). Sense of humor, emotional intelligence, and social competence. Journal of Research in Personality, 40, 1202-1208. http://dx.doi.org/10.1016/j.jrp.2005.08.005

York-Barr, J., \& Duke, K. (2004). What do we know about teacher leadership? Findings from two decades of scholarship. Review of Educational Research, 74(3), 255-316. http://dx.doi.org/10.3102/00346543074003255

Ziegler, V. F. (1982). A study of the relationship of principals' self-report humor scores and their leadership styles as perceived by teachers (Unpublished doctoral dissertation). Retrieved from ProQuest Dissertations and Theses database. (UMI No. 8227571)

Ziegler, V., \& Boardman, G. (1986). Humor: the seventh sense in leadership. National Forum of Educational Administration and Supervision, 2(2), 11-15.

Ziegler, V., Boardman, G., \& Thomas, M. D. (1985). Humor, leadership, and school climate. Clearing House, 58, 346-348. 


\section{Copyright Disclaimer}

Copyright reserved by the author(s).

This article is an open-access article distributed under the terms and conditions of the Creative Commons Attribution license (http://creativecommons.org/licenses/by/3.0/). 